Brazilian Journal

of Chemical

ISSN 0104-6632

Engineering

\title{
INHIBITION KINETICS DURING THE OXIDATION OF BINARY MIXTURES OF PHENOL WITH CATECHOL, RESORCINOL AND HYDROQUINONE BY PHENOL ACCLIMATED ACTIVATED SLUDGE
}

\author{
C. C. Lobo ${ }^{1 *}$, N. C. Bertola ${ }^{1}$ and E. M. Contreras ${ }^{2}$ \\ ${ }^{1}$ Centro de Investigación y Desarrollo en Criotecnología de Alimentos, (CIDCA), CONICET, \\ Fac. de Cs. Exactas, UNLP. 47 y 116 (B1900AJJ), La Plata, Argentina. \\ Phone: + 542214254853 \\ E-mail: cintiacecilialobo@hotmail.com \\ ${ }^{2}$ Instituto de Investigaciones en Ciencia y Tecnología de Materiales (INTEMA), CONICET-Mar \\ del Plata, Av. Juan B. Justo 4302, (7600) Mar del Plata, Argentina.
}

(Submitted: March 16, 2015 ; Accepted: April 23, 2015)

\begin{abstract}
In this work the aerobic degradation of phenol (PH), catechol (CA), resorcinol (RE), hydroquinone $(\mathrm{HY})$ and of the binary mixtures $\mathrm{PH}+\mathrm{CA}, \mathrm{PH}+\mathrm{RE}, \mathrm{PH}+\mathrm{HY}$ by phenol-acclimated activated sludge was studied. Single substrate experiments show a Haldane-type dependence of the respiration rate on PH, RE and HY, while CA corresponded to the Monod model. Binary substrate experiments demonstrated that the presence of a second substrate only affected the kinetics, but not the stoichiometry of the oxidation of the compounds tested. While CA inhibited the oxidation of $\mathrm{PH}, \mathrm{PH}$ inhibited the oxidation of RE and HY. A mathematical model was developed to represent the aerobic biodegradation of the phenolic compounds tested. The agreement between the proposed model and the experimental data indicates that the proposed model can be useful for predicting substrate and dissolved oxygen concentrations in bioreactors treating phenolic wastewaters.
\end{abstract}

Keywords: Phenolic compounds; Biodegradation; Respirometry; Activated sludge; Mathematical model.

\section{INTRODUCTION}

Due to the wide use of phenol and its derivatives, phenolic compounds are widespread in the environment. Several physico-chemical methods, such as adsorption, Fenton, photo Fenton, or combinations of these techniques can be used to remove phenolic compounds from industrial wastewater (Houari et al., 2014; Wang et al., 2014). However, in some cases these treatments utilize expensive reagents and generate chemical sludges that are frequently toxic
(Inchaurrondo et al., 2014). Conversely, most biological methods are simple to manage, utilize innocuous reagents (e.g., atmospheric oxygen), and produce biodegradable sludges. For these reasons, biological methods are widely used (Busca et al., 2008).

Wastewaters generated by chemical facilities are often extremely variable in terms of flowrate, composition and concentration of organic compounds, causing operational problems in continuous flow treatment systems (Edwards, 1995). Thus, despite the

*To whom correspondence should be addressed 
presence of equalizer tanks, actual facilities operate under transient conditions. Because steady-state conditions are assumed when sizing continuous flow bioreactors, wastewater treatment plants are generally designed with excess capacity to ensure the degradation under overload conditions. The utilization of biological processes for purification of toxic wastewaters emphasizes the practical requirement of developing adequate mathematical models to be used for the design and operation of these processes under transient conditions. The knowledge of microbial substrate utilization kinetics is important for the accurate prediction of the quality of the treatment process effluent. One key feature is the relationship between the concentrations of substrate and oxygen and their consumption rates (Arutchelvan et al., 2006; Kumar and Kumar, 2005; Nuhoglu and Yalcin, 2005). While the actual substrate consumption rate determines the size of bioreactors, knowledge of the oxygen uptake rate (OUR) is crucial for an appropriate design of aeration devices. For example, according to Vanrollehem and Gillot (2002), aeration costs represent about $45 \%$ of the total operational cost (e.g., aeration, pumping and sludge treatment) in a typical activated sludge wastewater treatment plant. Therefore, accurate kinetic parameters help engineers to optimize operational conditions in order to meet discharge requirements while minimizing costs.

Batch and semicontinuous processes employing suspended or immobilized biomass were used to study the phenol degradation kinetics (Karigar et al., 2006; Nuhoglu and Yalcin, 2005; Orupõld et al., 2001; Tziotzios et al., 2005; Yoong et al., 2000). Several studies have also focused attention on the aerobic biodegradation of single phenolic compounds and their mixtures by activated sludge (Bajaj et al., 2008; Lepik and Tenno, 2011; Pramparo et al., 2012). Considering that the knowledge of OUR is crucial for an appropriate design of aeration devices, the aim of this work was a study of the aerobic degradation of phenol $(\mathrm{PH})$, catechol $(\mathrm{CA})$, resorcinol (RE), hydroquinone (HY) and the binary mixtures $\mathrm{PH}+\mathrm{CA}, \mathrm{PH}+\mathrm{RE}, \mathrm{PH}+\mathrm{HY}$ by phenol-acclimated activated sludge. A mathematical model was developed to describe the aerobic degradation of binary mixtures of PH with CA, RE and HY by phenol-acclimated activated sludge. The model was calibrated using respirometric profiles corresponding to single solutions of phenol (PH), catechol (CA), resorcinol (RE), and hydroquinone (HY). Then, the proposed model was validated using respirometric profiles corresponding to the binary mixtures of phenolic compounds.

\section{MATERIALS AND METHODS}

\section{Chemicals and Reagents}

Phenol (PH) (loose crystals, > 99\%) and resorcinol (RE) (ACS reagent, $>99 \%$ ) were obtained from Sigma (St. Louis, MO, USA). Catechol (CA) and hydroquinone (HY) were analytical grade from Biomed Inc. (Aurora, Ohio). Dehydrated cheese whey was from Food S.A. (Villa Maipú, Argentina). All inorganic salts were commercial products of reagent grade from Anedra (San Fernando, Argentina).

\section{Acclimation Procedure and Culture Conditions}

Phenol-acclimated activated sludge was obtained from a laboratory scale $(2.5 \mathrm{~L})$ cylindrical semicontinuous fill and draw reactor. Aeration was provided at the bottom of the reactor through an air-stone using two air pumps at $2 \mathrm{~L} \mathrm{~min}^{-1}$; the dissolved oxygen (DO) concentration was maintained above $4 \mathrm{mgO}_{2} \mathrm{~L}^{-1}$. The reactor was fed with the following culture medium with $\mathrm{PH}$ as the sole carbon-limiting source (Nuhoglu and Yalcin, 2005): $\left(\mathrm{NH}_{4}\right)_{2} \mathrm{SO}_{4} 226 \mathrm{mg} \mathrm{L}^{-1}$, $\mathrm{K}_{2} \mathrm{HPO}_{4} 500 \mathrm{mg} \mathrm{L}^{-1} \mathrm{KH}_{2} \mathrm{PO}_{4} 250 \mathrm{mg} \mathrm{L}^{-1} \mathrm{MgSO}_{4} .7 \mathrm{H}_{2} \mathrm{O}$ $25.2 \mathrm{mg} \mathrm{L}^{-1}, \mathrm{MnSO}_{4} \cdot \mathrm{H}_{2} \mathrm{O} 2.52 \mathrm{mg} \mathrm{L}^{-1}, \mathrm{CaCl}_{2} 2 \mathrm{mg} \mathrm{L}^{-1}$, $\mathrm{FeCl}_{3} 1.2 \mathrm{mg} \mathrm{L}^{-1}$, phenol $300 \mathrm{mg} \mathrm{L}^{-1}$. The $\mathrm{pH}$ was adjusted to $7.0 \pm 0.05$ by adding a few drops of concentrated solutions of $\mathrm{NaOH}$ or $\mathrm{HCl}$. During this phase the solids retention time was 45 days to prevent the biomass washout. The reactor was monitored periodically by measurements of total suspended solids (TSS), soluble chemical oxygen demand (COD) consumption rate, and total phenols $(\mathrm{TPh})$ consumption rate. The biomass was considered to be acclimated to phenol when the specific consumption rates of COD and $\mathrm{TPh}$ were constant for at least two weeks. This phenol-acclimated activated sludge was used in all further experiments.

\section{Respirometric Assays}

The aerobic degradation kinetics of the tested compounds (phenol, resorcinol, catechol, and hydroquinone) by phenol-acclimated activated sludge was assessed using an open (flowing gas/static liquid) respirometer. Activated sludge samples $(500 \mathrm{~mL})$ were washed three times using a phosphate buffer $(15 \mathrm{mM}, \mathrm{pH}=7)$ and resuspended using $500 \mathrm{~mL}$ of the above mentioned buffer. Then, $0.5 \mathrm{~mL}$ of micronutrient solutions $\mathrm{M} 1$ and M2 were added. The composition of $\mathrm{M} 1$ was $(\mathrm{g} / 100 \mathrm{~mL}): \mathrm{FeSO}_{4} \cdot 7 \mathrm{H}_{2} \mathrm{O} 1.5$, $\mathrm{ZnSO}_{4} .7 \mathrm{H}_{2} \mathrm{O} 0.5, \mathrm{MnSO}_{4} \cdot \mathrm{H}_{2} \mathrm{O} 0.3, \mathrm{CuSO}_{4} .5 \mathrm{H}_{2} \mathrm{O} 0.075$, $\mathrm{CoCl}_{2} \cdot 6 \mathrm{H}_{2} \mathrm{O}$ 0.015, and citric acid 0.6. Micronutrient 
solution $\mathrm{M} 2$ contained the following $(\mathrm{g} / 100 \mathrm{~mL})$ : $\left(\mathrm{NH}_{4}\right)_{6} \mathrm{Mo}_{7} \mathrm{O}_{24} .4 \mathrm{H}_{2} \mathrm{O} \quad 0.05, \mathrm{BO}_{3} \mathrm{H}_{3} 0.01$, KI 0.01 (Lobo et al., 2013).

$500 \mathrm{~mL}$ of washed activated sludge were poured into the respirometer. Agitation was provided by a magnetic stir-bar; the respirometer was continuously aerated by an air pump. Air was set to a stable flow rate $\left(1.0 \mathrm{~L} \mathrm{~min}^{-1}\right)$ using a high precision rotameter (Bruno Schilling model MB 60V, Argentina). The operation temperature was $20 \pm 1{ }^{\circ} \mathrm{C}$. Before the addition of the tested compound, the oxygen mass transfer coefficient of the respirometer $\left(\mathrm{k}_{\mathrm{L}} \mathrm{a}\right)$ and the endogenous oxygen uptake rate $\left(\mathrm{OUR}_{\text {end }}\right)$ were obtained using a non-steady state procedure (Lobo et al., 2014). According to the experimental conditions, such as biomass concentration and the compound tested, the $\mathrm{k}_{\mathrm{L}}$ a values employed ranged between 10 and $40 \mathrm{~h}^{-1}$. When a stable DO concentration was obtained, the respirometer was spiked with the tested compound and the dissolved oxygen concentration (C) was recorded as a function of time ( $t$ ). The oxygen uptake rate associated with the substrate oxidation $\left(\mathrm{OUR}_{\mathrm{ex}}\right)$ was calculated from the DO mass balance in the respirometer:

$$
\frac{\mathrm{dC}}{\mathrm{dt}}=\mathrm{k}_{\mathrm{L}} \mathrm{a}\left(\mathrm{C}_{\mathrm{e}}-\mathrm{C}\right)-\mathrm{OUR}_{\mathrm{ex}}
$$

where $\mathrm{C}_{\mathrm{e}}$ is the DO concentration in the absence of an oxidizable substrate and $\mathrm{C}$ is the instantaneous DO concentration. From the DO profile as a function

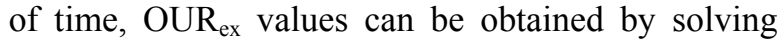
Eq. (1) for OUR $\mathrm{O}_{\text {ex }}$. Then the oxygen consumed (OC) during the oxidation of the tested compound can be calculated as follows:

$$
\mathrm{OC}=\int_{0}^{\mathrm{t}} \mathrm{OUR}_{\mathrm{ex}} \mathrm{dt}
$$

At a given time $t=t_{\mathrm{f}}$ the substrate was depleted and $\mathrm{OUR}_{\mathrm{ex}}$ values returned to zero. Thus, the OC value at time $t_{f}$ corresponded to the total oxygen consumed $\left(\mathrm{OC}_{\mathrm{T}}\right)$ during the oxidation of the tested compound. In the case of repeated additions of one or more substrates, the cumulative oxygen consumption $(\operatorname{Sum}(\mathrm{OC}))$ was calculated as the sum over the individual $\mathrm{OC}_{\mathrm{T}}$ values. For all the tested compounds, abiotic control experiments (e.g., without biomass) were negative with regard to the oxygen consumption (data not shown).

\section{Analytical Procedures}

Total suspended solids (TSS, $\mathrm{mg} / \mathrm{L}$ ) were used as a measure of the biomass concentration in the respi- rometer. Known sample volumes ( $8 \mathrm{~mL}$ in this work) were poured into pre-weighed centrifuge tubes, centrifuged and washed twice with distilled water, and incubated at $105{ }^{\circ} \mathrm{C}$ for $24 \mathrm{~h}$; the TSS of each sample was calculated as the difference between the final weight (dry sample + tube) and initial weight (tube alone) divided by the sample volume. Duplicate biomass measurements were performed to reduce experimental errors; average and maximum relative errors for TSS were $4 \%$ and $13 \%$, respectively. The DO concentration was measured using a YSI (model 5739) polarographic DO probe; data were acquired on a personal computer interfaced to a YSI (model 58) DO monitor at 1 measurement/sec.

\section{Estimation of the Model Coefficients and Dynamic Simulations}

Calculation of the coefficients of the mathematical model proposed in this work and the dynamic simulations were performed using the software package Gepasi 3 (Mendes, 1993). The routine LSODA (Livermore Solver of Ordinary Differential Equations) was selected to integrate the system of differential equations of the proposed model. The Multistart Optimization algorithm (with Levenberg-Marquardt local optimization) was selected to fit the proposed model to the experimental data. To describe the biological start-up phenomenon, a first order correction factor was included (Contreras et al., 2008).

\section{RESULTS AND DISCUSSION}

\section{Oxidation of Single Phenolic Compounds by Phe- nol-Acclimated Activated Sludge}

Figures 1 and 2 show typical examples of the DO profile and the corresponding exogenous oxygen uptake rate $\left(\mathrm{OUR}_{\mathrm{ex}}\right)$ as a function of time $(\mathrm{t})$ during the biodegradation of phenol $(\mathrm{PH})$, catechol $(\mathrm{CA})$, resorcinol (RE) and hydroquinone (HY) by phenolacclimated activated sludge. As a general rule, substrate and oxygen uptake rates corresponding to the biodegradation of PH and CA (Fig. 1) were about 4 to 6 times higher than those corresponding to RE or HY (Fig. 2). During the biodegradation of PH and $\mathrm{CA}, \mathrm{OUR}_{\mathrm{ex}}$ values rapidly increased towards a given maximum. Then, $\mathrm{OUR}_{\mathrm{ex}}$ decreased to a new pseudo steady-state value (Fig. 1b,d) caused by DO concentrations lower than $0.1 \mathrm{mM}$ (Fig. 1a,c), which led to a DO limitation condition. The presence of these peaks in the OUR $\mathrm{Rx}_{\mathrm{ex}}$ profiles due to an oxygen limitation of the external substrate oxidation was also reported by several authors (Contreras et al., 2008; 


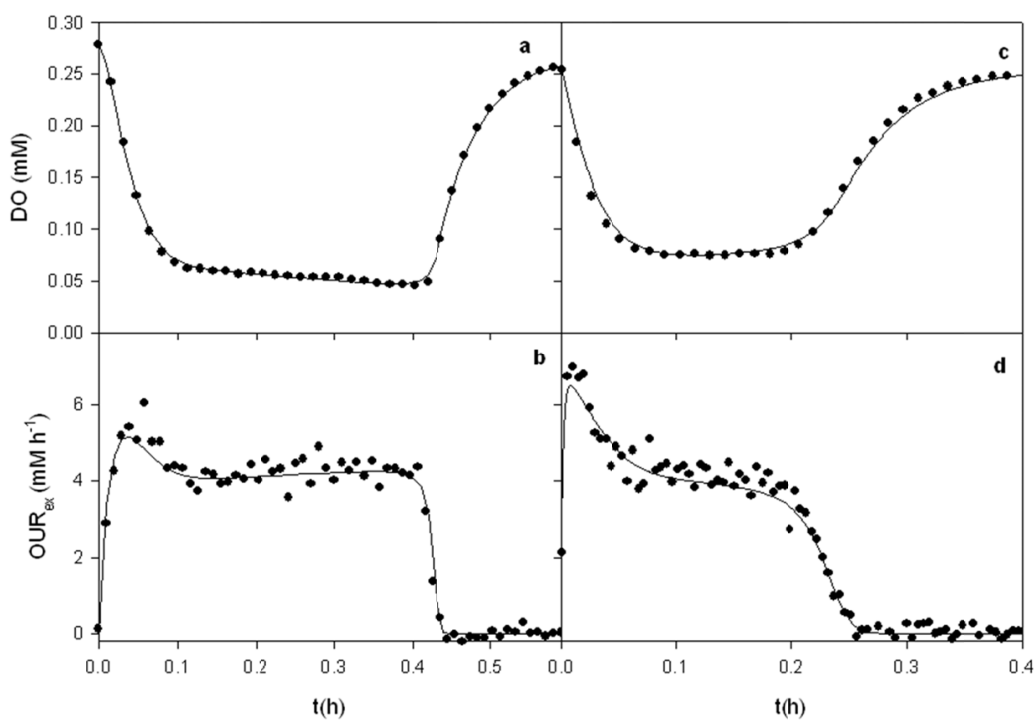

Figure 1: Typical examples of DO profiles $(a, c)$ and the corresponding $\operatorname{OUR}_{\mathrm{ex}}(\mathrm{b}, \mathrm{d})$ during the biodegradation of phenol $(\mathrm{a}, \mathrm{b})$ and catechol $(\mathrm{c}, \mathrm{d})$ by phenol-acclimated activated sludge. Lines indicate the proposed model (Eqs. (3) to (6)). Experimental conditions: (a,b) $\mathrm{X}=3.1 \mathrm{gTSS} \mathrm{L}^{-1}, \mathrm{k}_{\mathrm{L}} \mathrm{a}=19 \mathrm{~h}^{-1}, \mathrm{~S}_{0}=1.06 \mathrm{mM}$; (c,d) X $=1.3 \mathrm{gTSS} \mathrm{L}^{-1}$, $\mathrm{k}_{\mathrm{L}} \mathrm{a}=23 \mathrm{~h}^{-1}, \mathrm{~S}_{0}=0.91 \mathrm{mM}$.

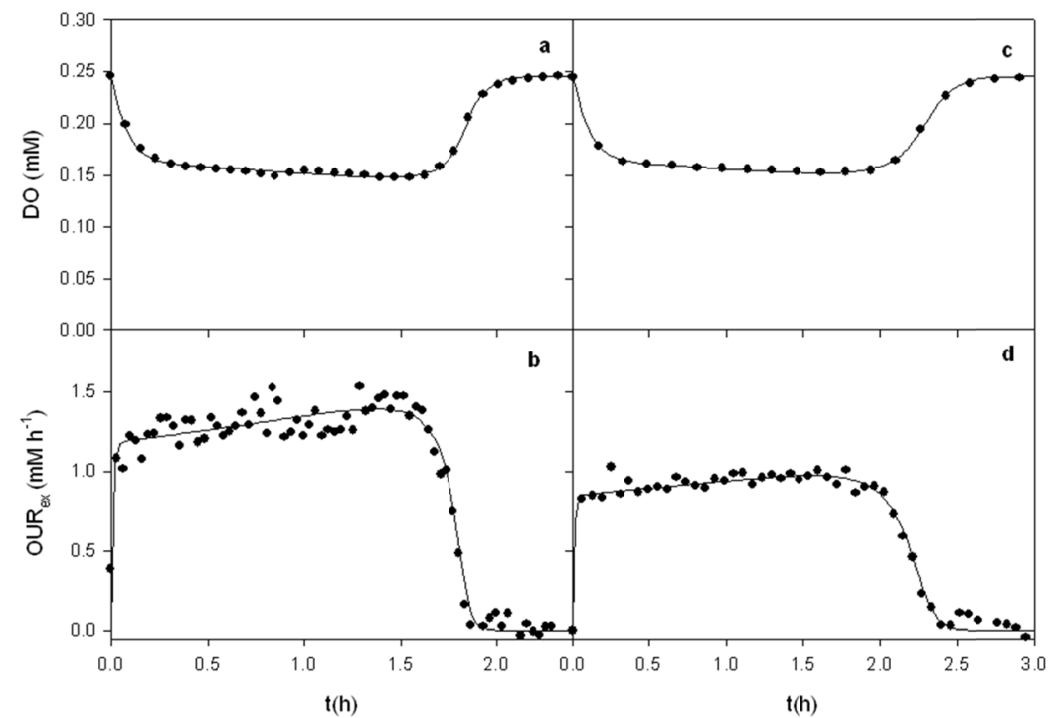

Figure 2: Typical examples of DO profiles $(\mathrm{a}, \mathrm{c})$ and the corresponding $\mathrm{OUR}_{\mathrm{ex}}(\mathrm{b}, \mathrm{d})$ during the biodegradation of resorcinol $(\mathrm{a}, \mathrm{b})$ and hydroquinone $(\mathrm{c}, \mathrm{d})$ by phenol-acclimated activated sludge. Lines indicate the fitted kinetic model (Eqs. (3) to (6)). Experimental conditions: (a,b) $\mathrm{X}=2.1 \mathrm{gTSS} \mathrm{L}^{-1}, \mathrm{k}_{\mathrm{L}} \mathrm{a}=14 \mathrm{~h}^{-1}, \mathrm{~S}_{0}=0.91 \mathrm{mM}$; (c,d) $\mathrm{X}=$ $2.7 \mathrm{gTSS} \mathrm{L}^{-1}, \mathrm{k}_{\mathrm{L}} \mathrm{a}=10 \mathrm{~h}^{-1}, \mathrm{~S}_{0}=0.91 \mathrm{mM}$.

Guisasola et al., 2006). Because of the low OUR obtained during the biodegradation of RE and HY (Fig. 2b,d), in all cases the DO values were higher than $0.15 \mathrm{mM}$ (Fig. 2a,c). The absence of the above mentioned $\mathrm{OUR}_{\mathrm{ex}}$ peaks when RE and HY were spiked in the respirometer suggests that, within the tested conditions, the effect of the DO concentration on RE and HY biodegradation kinetics was negligible.

\section{Oxidation of Binary Mixtures of Phenolic Com- pounds by Phenol-Acclimated Activated Sludge}

Figures 3 to 5 show DO and the corresponding OUR $_{\text {ex }}$ profiles during the degradation of binary mixtures of the tested compounds. For all the tested compounds, respiration rates of phenol-acclimated activated sludge in the presence of $\mathrm{PH}, \mathrm{CA}, \mathrm{RE}$ and $\mathrm{HY}$ 
were approximately constant as a function of the test number. In a previous work, Lobo et al. (2013) demonstrated that repeated additions of $\mathrm{PH}$ and $\mathrm{HY}$ had a negligible effect on PH and HY consumption rates. Those authors also reported that the cumulative substrate (CA, RE) concentrations necessary to reduce by $50 \%$ the biodegradation rate $\left(\mathrm{IC}_{50}\right)$ of $\mathrm{CA}$ or $\mathrm{RE}$ were 7.5 and $8.0 \mathrm{mM}$, respectively. Although repeated additions of $\mathrm{CA}$ or $\mathrm{RE}$ were performed in the present work (Figs. 3 and 4), maximum cumulative substrate concentrations were $5.4 \mathrm{mM}$, which was lower than $\mathrm{IC}_{50}$ corresponding to these compounds (Lobo et al., 2013). Moreover, in the present work, every addition of CA or RE was followed by the addition of $\mathrm{PH}$, which could have a protective effect against the toxicity of these compounds. For these reasons, in the present work the effects of repeated additions of CA or RE on their consumption rates were negligible.

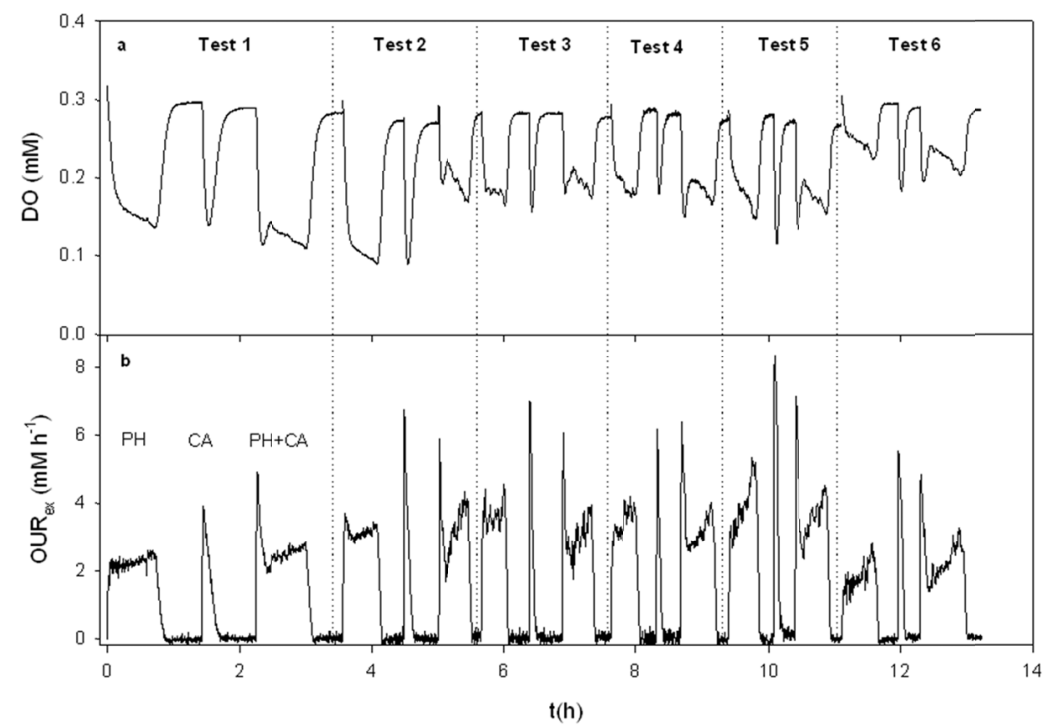

Figure 3: DO profile (a) and the corresponding $\mathrm{OUR}_{\mathrm{ex}}(\mathrm{b})$ during the biodegradation of phenol (PH, $\left.1.06 \mathrm{mM}\right)$, catechol (CA, $0.45 \mathrm{mM})$, and the mixture of phenol $(1.06 \mathrm{mM})$ and catechol $(0.45 \mathrm{mM})(\mathrm{PH}+\mathrm{CA})$ by phenolacclimated activated sludge. Dotted lines indicate each cycle of addition of substrates.

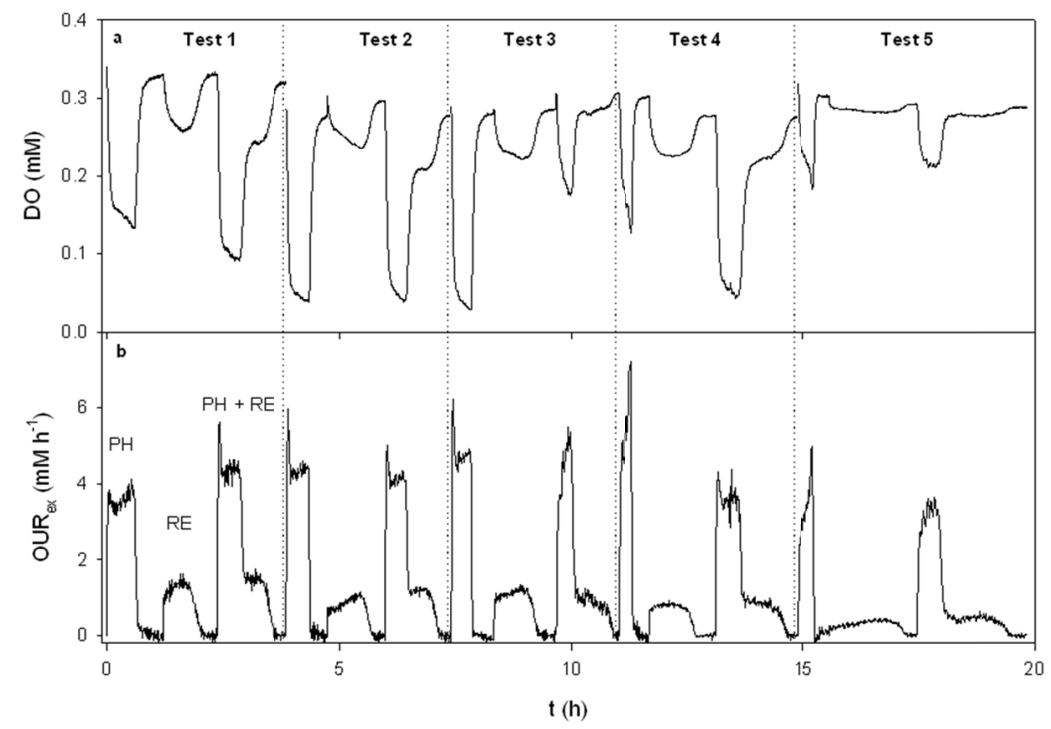

Figure 4: DO profile (a) and the corresponding $\mathrm{OUR}_{\mathrm{ex}}$ (b) during the biodegradation of phenol (PH, $\left.1.06 \mathrm{mM}\right)$, resorcinol (RE, $0.45 \mathrm{mM})$, and the mixture of phenol $(1.06 \mathrm{mM})$ and resorcinol $(0.45 \mathrm{mM})(\mathrm{PH}+\mathrm{RE})$ by phenolacclimated activated sludge. Dotted lines indicate each cycle of addition of substrates. 


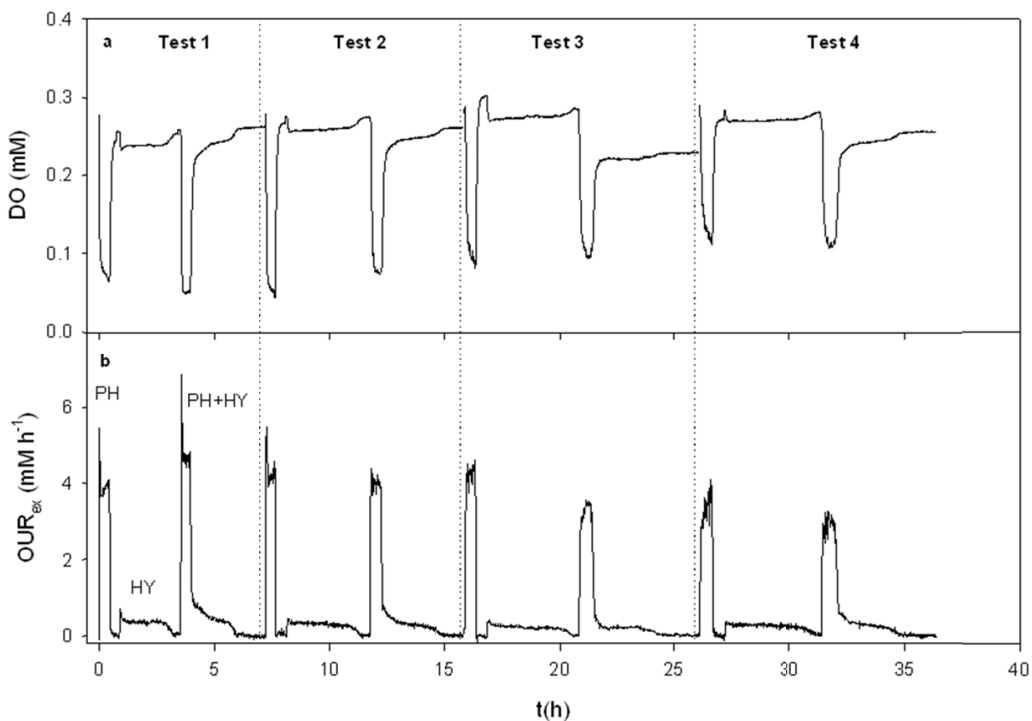

Figure 5: DO profile (a) and the corresponding $\mathrm{OUR}_{\mathrm{ex}}$ (b) during the biodegradation of phenol (PH, $\left.1.06 \mathrm{mM}\right)$, hydroquinone $(\mathrm{HY}, 0.45 \mathrm{mM})$, and the mixture of phenol $(1.06 \mathrm{mM})$ and hydroquinone $(0.45 \mathrm{mM})(\mathrm{PH}+\mathrm{HY})$ by phenol-acclimated activated sludge. Dotted lines indicate each cycle of addition of substrates.

Figure 6a shows that the maximum $\mathrm{OUR}_{\mathrm{ex}}$ values corresponding to $\mathrm{CA}$ were higher than those corresponding to $\mathrm{PH}$. However, the maximum OUR $\mathrm{ex}_{\mathrm{x}}$ value corresponding to the mixture $\mathrm{PH}+\mathrm{CA}$ was close to that obtained during the addition of $\mathrm{CA}$ alone. This result indicates that the $\mathrm{OUR}_{\mathrm{ex}}$ profile corresponding to the binary mixture of $\mathrm{PH}$ and $\mathrm{CA}$ cannot be represented by the sum of profiles corresponding to each single compound. Moreover, the results suggest that, during the first phase of the respirogram corresponding to the mixture $\mathrm{PH}+\mathrm{CA}, \mathrm{CA}$ inhibited the metabolism of $\mathrm{PH}$; for this reason, the maximum OUR $\mathrm{Ox}_{\mathrm{ex}}$ values corresponding to the mixture $\mathrm{PH}+\mathrm{CA}$ were close to those obtained during the addition of $\mathrm{CA}$ alone.
However, because CA was actively oxidized, its concentration diminished below a certain value, allowing the oxidation of $\mathrm{PH}$; under this condition, the second phase of the respirogram represents the oxidation of $\mathrm{PH}$. Figure $6 \mathrm{~b}, \mathrm{c}$ shows that the initial parts of the $\mathrm{OUR}_{\mathrm{ex}}$ profiles corresponding to the mixtures $\mathrm{PH}+\mathrm{RE}$ and $\mathrm{PH}+\mathrm{HY}$ were also close to those obtained during the addition of $\mathrm{PH}$ alone. Similarly to the respirograms corresponding to the mixture $\mathrm{PH}+\mathrm{CA}$ (Fig. 6a), Figure $6 \mathrm{~b}, \mathrm{c}$ shows that the respirograms obtained during the oxidation of $\mathrm{PH}+\mathrm{RE}$ or $\mathrm{PH}+\mathrm{HY}$ can also be divided into two phases. However, in these cases, the first part represents the oxidation of $\mathrm{PH}$, while the second phase corresponds to the oxidation of RE or HY.
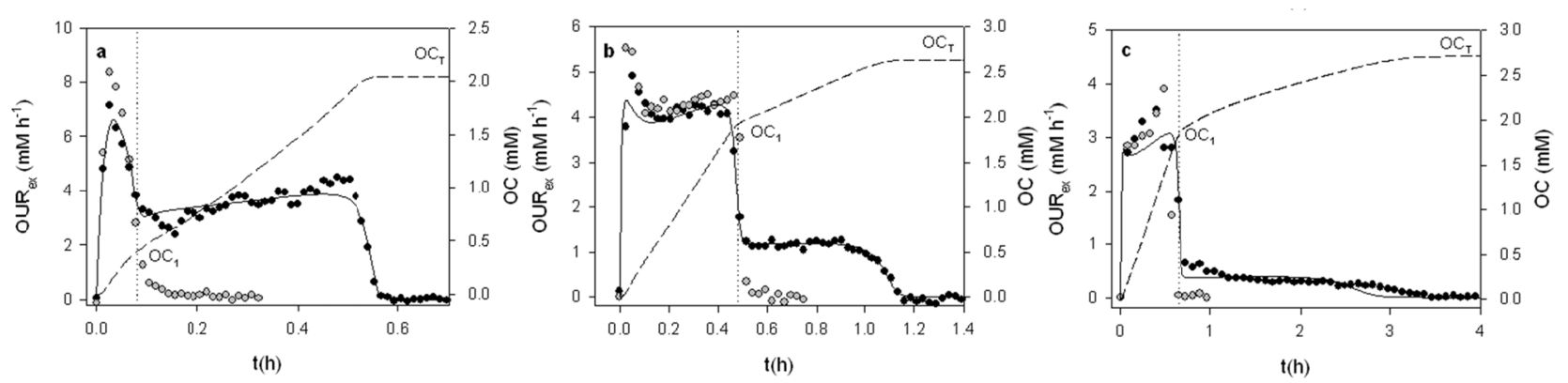

Figure 6: Examples of oxygen uptake rate (OUR $\mathrm{Ox}_{\mathrm{e}}$, circles) and oxygen consumed (OC, dashed lines) during the oxidation of: a) $\mathrm{PH}+\mathrm{CA}$ (black) and $\mathrm{CA}$ alone (grey), b) $\mathrm{PH}+\mathrm{RE}$ (black) and $\mathrm{PH}$ alone (grey), c) $\mathrm{PH}+\mathrm{HY}$ (black) and $\mathrm{PH}$ alone (grey). Dotted lines indicate the time corresponding to the end of the first phase of the respirogram. $\mathrm{OC}_{1}=\mathrm{OC}$ of the first phase, $\mathrm{OC}_{\mathrm{T}}=$ total OC. Continuous lines represent the proposed model (Eqs. (3) to (6)) 


\section{Modelling the Oxidation of Single Substrates and Binary Mixtures of Phenolic Compounds}

Among the various substrate inhibition models, the Haldane equation has been widely used to describe the aerobic degradation kinetics of phenol and phenolic compounds (Christen et al., 2012; Lepik and Tenno, 2011; Pramparo et al., 2012). In the case of CA, Figure 1b suggests that the biodegradation rate obeyed a Monod-type equation with respect to CA within the tested concentrations. In addition, a similar expression is usually included to take into account the effect of the dissolved oxygen concentration (C) on substrate and oxygen consumption rates (Contreras et al., 2008; Guisasola et al., 2006). However, due to the low $\mathrm{OUR}_{\mathrm{ex}}$ values obtained when RE or HY were tested (Fig. 2), the DO concentration had a negligible effect on RE and $\mathrm{HY}$ biodegradation rates. To represent the effect of an inhibitor on a given bioprocess, the noncompetitive inhibition model is one of the most used. For example, in the Activated Sludge Model No. 1 (ASM1) and its progeny (ASM2, ASM3), the inhibition of denitrification by dissolved oxygen is modelled using this approach (Gujer et al., 1999; Henze et al., 1987; Henze et al., 1999). Finally, it was assumed that, in the presence of several substrates, the oxygen consumption rate can be represented by the sum of OUR corresponding to each substrate; moreover, the presence of a second substrate only affects the kinetics, but not the stoichiometry of the oxidation of the tested compounds.

Based on these considerations, the following expressions for the consumption rates corresponding to $\mathrm{PH}\left(\mathrm{R}_{\mathrm{PH}}\right), \mathrm{CA}\left(\mathrm{R}_{\mathrm{CA}}\right), \mathrm{RE}$ and $\mathrm{HY}\left(\mathrm{R}_{\mathrm{Z}}\right)$ and oxygen $\left(\mathrm{OUR}_{\mathrm{ex}}\right)$ were proposed:

$$
\begin{aligned}
& \mathrm{R}_{\mathrm{PH}}=\mathrm{q}_{\mathrm{SmPH}}\left(\frac{\mathrm{PH}}{\mathrm{K}_{\mathrm{SPH}}+\mathrm{PH}+\mathrm{PH}^{2} / \mathrm{K}_{\mathrm{iPH}}}\right)\left(\frac{\mathrm{C}}{\mathrm{K}_{\mathrm{O} 2 \mathrm{PH}}+\mathrm{C}}\right)\left(\frac{\mathrm{K}_{\mathrm{inP} / \mathrm{CA}}}{\mathrm{K}_{\mathrm{inPH} / \mathrm{CA}}+\mathrm{CA}}\right) \mathrm{X} \\
& \mathrm{R}_{\mathrm{CA}}=\mathrm{q}_{\mathrm{SmCA}}\left(\frac{\mathrm{CA}}{\mathrm{K}_{\mathrm{SCA}}+\mathrm{CA}}\right)\left(\frac{\mathrm{C}}{\mathrm{K}_{\mathrm{O} 2 \mathrm{CA}}+\mathrm{C}}\right) \mathrm{X} \\
& \mathrm{R}_{\mathrm{Z}}=\mathrm{q}_{\mathrm{SmZ}}\left(\frac{\mathrm{Z}}{\mathrm{K}_{\mathrm{S}}+\mathrm{Z}+\mathrm{Z}^{2} / \mathrm{K}_{\mathrm{iZ}}}\right)\left(\frac{\mathrm{K}_{\mathrm{inZ} / \mathrm{PH}}}{\mathrm{K}_{\mathrm{inZ} / \mathrm{PH}}+\mathrm{PH}}\right) \mathrm{X} \\
& \mathrm{OUR}_{\mathrm{ex}}=\mathrm{Y}_{\mathrm{O} / \mathrm{PH}} \mathrm{R}_{\mathrm{PH}}+\mathrm{Y}_{\mathrm{O} / \mathrm{CA}} \mathrm{R}_{\mathrm{CA}}+\mathrm{Y}_{\mathrm{O} / \mathrm{Z}} \mathrm{R}_{\mathrm{Z}}
\end{aligned}
$$

where,

$\mathrm{Z}$ represents RE or HY. The term $\left(\frac{\mathrm{K}_{\mathrm{inPH} / \mathrm{CA}}}{\mathrm{K}_{\mathrm{inPH} / \mathrm{CA}}+\mathrm{CA}}\right)$

in Eq. (3) corresponds to the inhibition of the $\mathrm{PH}$ oxidation due to the presence of $\mathrm{CA}, \mathrm{K}_{\mathrm{inPH} / \mathrm{CA}}$ being the inhibition constant. For a given CA concentration, the lower the $\mathrm{K}_{\mathrm{inPH} / \mathrm{CA}}$ value, the higher the inhibition; thus, a low $\mathrm{K}_{\mathrm{inPH} / \mathrm{CA}}$ value indicates a strong inhibition of the oxidation of $\mathrm{PH}$ by $\mathrm{CA}$. According to Figure 6, PH is oxidized first and then RE of HY.

For this reason, the term $\left(\frac{\mathrm{K}_{\mathrm{inZ} / \mathrm{PH}}}{\mathrm{K}_{\mathrm{inZ} / \mathrm{PH}}+\mathrm{PH}}\right)$ that represents the inhibition of the oxidation of $\mathrm{Z}$ (e.g., RE or $\mathrm{HY}$ ) by $\mathrm{PH}$ was included in Eq. (5), $\mathrm{K}_{\mathrm{inZ} / \mathrm{PH}}$ being the inhibition constant. Although the proposed model (Eqs. (3) to (6)) has 20 coefficients, 17 of them can be estimated based on the $\mathrm{OUR}_{\mathrm{ex}}$ profiles corresponding to the single compounds (Figs. 1 and 2). However, binary substrate respirometric experiments (Figs. 3 to 5) were necessary to evaluate the inhibition constants $\mathrm{K}_{\mathrm{inPH} / \mathrm{CA}}, \mathrm{K}_{\mathrm{inRE} / \mathrm{PH}}$ and $\mathrm{K}_{\mathrm{inHY} / \mathrm{PH}}$.

In a first step, the model proposed in the present work was fitted to the respirometric profiles (e.g., DO concentration as a function of time) corresponding to the single phenolic compounds. Figures 1 and 2 show that, using the coefficients depicted in Table 1 , the proposed model adequately represented DO and $\mathrm{OUR}_{\mathrm{ex}}$ profiles during the degradation of all the tested compounds. Table 1 shows that the maximum specific substrate consumption rate $\left(\mathrm{q}_{\mathrm{Sm}}\right)$ corresponding to $\mathrm{PH}$ was 7- and 9-fold greater than the values corresponding to RE or HY, respectively. Moreover, the $\mathrm{q}_{\mathrm{Sm}}$ value corresponding to CA was about 4 times the value corresponding to $\mathrm{PH}$, suggesting that during the metabolism of $\mathrm{PH}$ there was no accumulation of CA. Based on the values of $\mathrm{q}_{\mathrm{sm}}$ (Table 1), the tested phenolic compounds can be ordered as follows: $\mathrm{CA}>\mathrm{PH}>\mathrm{RE}>\mathrm{HY}$. This order of metabolism rates agrees with other authors that studied the oxygen consumption rate in the presence of phenolic compounds by intact cells, and enzyme (cell-free) preparations (Ahuatzi-Chacón et al., 2004; Lepik and Tenno, 2011; Lobo et al., 2013, 2014; Orupõld et al., 2001). Table 1 shows that the values corresponding to the coefficients $\mathrm{K}_{\mathrm{S}}$, and $\mathrm{K}_{\mathrm{i}}$ had relative errors ranging from 30 to $53 \%$. However, it is known that the sensitivity of OUR with respect to $K_{i}$ is rather low (e.g., a high variation of $\mathrm{K}_{\mathrm{i}}$ has a small effect on OUR). For this reason, large variations in the estimation of $\mathrm{K}_{\mathrm{i}}$ are frequently obtained when OUR measurements are used to evaluate this parameter (Guisasola et al., 2006). 
Table 1: Kinetic coefficients corresponding to the aerobic degradation of phenol (PH), catechol (CA), resorcinol (RE) and hydroquinone (HY) by phenol-acclimated activated sludge (mean \pm confidence interval at a $95 \%$ confidence level are reported)

\begin{tabular}{|c|c|c|c|c|c|}
\hline & $\begin{array}{c}\mathbf{q}_{\mathbf{S m}} \\
\left(\mathbf{m m o l} \mathbf{g T S S}^{\mathbf{- 1}} \mathbf{h}^{\mathbf{- 1}}\right)\end{array}$ & $\begin{array}{c}\mathbf{K}_{\mathbf{S}} \\
(\mathbf{m M})\end{array}$ & $\begin{array}{c}\mathbf{K}_{\mathbf{i}} \\
(\mathbf{m M})\end{array}$ & $\begin{array}{c}\mathbf{K}_{\mathbf{O} 2} \\
(\mathbf{m M})\end{array}$ & $\begin{array}{c}\mathbf{Y}_{\mathbf{O} / \mathbf{s}} \\
(\mathbf{m o l} / \mathbf{m o l})\end{array}$ \\
\hline PH & $1.82 \pm 0.26$ & $0.021 \pm 0.004$ & $2.1 \pm 0.6$ & $0.06^{*}$ & $1.52 \pm 0.07$ \\
CA & $7.40 \pm 1.21$ & $0.045 \pm 0.030$ & n.a. & $0.087 \pm 0.018$ & $0.87 \pm 0.13$ \\
RE & $0.26 \pm 0.11$ & $0.013 \pm 0.004$ & $3.6 \pm 1.4$ & n.a. & $2.04 \pm 0.11$ \\
HY & $0.20 \pm 0.04$ & $0.029 \pm 0.010$ & $1.7 \pm 0.5$ & n.a. & $2.05 \pm 0.41$ \\
\hline
\end{tabular}

n.a.: not applicable

* from Contreras et al. (2008)

The $\mathrm{Y}_{\mathrm{O} / \mathrm{S}}$ values obtained (Table 1) are in accordance with those reported by other authors (Divari et al., 2003; Lepik and Tenno, 2011; Lobo et al., 2013; Orupõld et al., 2001). Table 1 shows that, within the experimental error, $1.5 \mathrm{~mol}$ of oxygen is consumed by phenol-acclimated activated sludge during the oxidation of one mol of $\mathrm{PH}$ under the tested conditions. Taking into account that the activated sludge studied also readily oxidized CA, and that about 1 mol of oxygen is consumed per mol of CA oxidized (Table 1), it is concluded that, during the first oxidation step of $\mathrm{PH}$ to $\mathrm{CA}$, only $0.5 \mathrm{~mol}$ of oxygen is consumed per mol of $\mathrm{PH}$ oxidized under the tested conditions.

Several authors report that the stoichiometry of $\mathrm{PH}$ oxidation by in vitro preparations of PHMO in the presence of NADPH is one mol of oxygen consumed per mol of $\mathrm{PH}$ oxidized, producing one mol of CA (Detmer and Massey, 1985; Enroth et al., 1998; Sejlitz and Neujahr, 1987). It must be pointed out that most of these studies were performed using a PHMO isolated from an eukaryote, the soil yeast Trichosporon cutaneum. However, activated sludge is mainly comprised of bacteria (Henze et al., 2002); thus, this difference could be the reason that the stoichiometric coefficient corresponding to the oxygen consumption during the oxidation of phenol to catechol obtained in this work was one half the value reported by other authors.

To represent the oxygen uptake rate (OUR) in the presence of more than one phenolic compound (Eq. (6)), it was assumed that the observed oxygen consumption rate is the sum of the OUR corresponding to each substrate. This hypothesis was tested as follows. According to Lobo et al. (2013), in the case of repeated additions of a single substrate, the cumulative oxygen consumption (Sum(OC)) can be calculated as the product between the cumulative substrate concentration $(\operatorname{Sum}(\mathrm{S}))$ and the corresponding oxidation coefficient $\left(\mathrm{Y}_{\mathrm{O} / \mathrm{S}}\right)$. In the case of binary mixtures, if both oxidation coefficients were not affected by the presence of the other substrate, the cumulative oxygen consumption (Sum(OC)) corresponding to a binary mixture composed of $\mathrm{PH}$ and a given compound $\mathrm{S}$ can be calculated as follows:

$$
\operatorname{Sum}(\mathrm{OC})_{\text {calc }}=\mathrm{Y}_{\mathrm{O} / \mathrm{PH}} \operatorname{Sum}(\mathrm{PH})+\mathrm{Y}_{\mathrm{O} / \mathrm{S}} \operatorname{Sum}(\mathrm{S})
$$

where $\mathrm{S}$ represents $\mathrm{CA}, \mathrm{RE}$ or $\mathrm{HY}, \mathrm{Y}_{\mathrm{O} / \mathrm{PH}}$ is the $\mathrm{PH}$ oxidation coefficient, and $\mathrm{Y}_{\mathrm{O} / \mathrm{S}}$ corresponds to the oxidation coefficient of CA, RE or HY. Figure 7 shows that using the oxidation coefficients depicted in Table 1, Eq. (7) satisfactorily predicts the oxygen consumed due to the oxidation of the tested phenolic compounds and of the binary mixtures composed of $\mathrm{PH}$ and CA, RE or HY. Additionally, $78 \%$ of the calculated $\operatorname{Sum}(\mathrm{OC})$ values using Eq. (7) were within $\pm 15 \%$ of the experimental values, with $-19 \%$ and $+26 \%$ being the minimum and maximum relative deviations, respectively. These results indicate that, within the experimental errors, oxidation coefficients corresponding to $\mathrm{PH}, \mathrm{CA}, \mathrm{RE}$, and $\mathrm{HY}$ can be considered to be independent with respect to the presence of another phenolic compound in a binary mixture, confirming the validity of Eq. (6).

Figure 6a suggests that, for the mixture $\mathrm{PH}+\mathrm{CA}$, CA was metabolized first and then PH. For this reason, an inhibition term of $\mathrm{PH}$ consumption due to the presence of CA was included in Eq. (3). To evaluate the inhibition constant $\mathrm{K}_{\mathrm{inPH} / \mathrm{CA}}$, the fraction of $\mathrm{PH}$ that was consumed during the first phase of the respirogram corresponding to the binary mixture $\mathrm{PH}+\mathrm{CA}$ was calculated as follows. According to Figure 7, the oxidation coefficients corresponding to the single compounds were not affected by the presence of a second phenolic compound. Thus, the oxygen consumed (OC) during the oxidation of the binary mixture $\mathrm{PH}+\mathrm{CA}$ can be calculated as follows:

$$
\mathrm{OC}=\mathrm{Y}_{\mathrm{O} / \mathrm{PH}}\left(\mathrm{PH}_{0}-\mathrm{PH}\right)+\mathrm{Y}_{\mathrm{O} / \mathrm{CA}}\left(\mathrm{CA}_{0}-\mathrm{CA}\right)
$$

where $\mathrm{PH}_{0}$ and $\mathrm{CA}_{0}$ represent the initial $\mathrm{PH}$ and $\mathrm{CA}$ concentrations, respectively. The total $\mathrm{OC}\left(\mathrm{OC}_{\mathrm{T}}\right)$ is 
reached when both compounds are completely consumed:

$\mathrm{OC}_{\mathrm{T}}=\mathrm{Y}_{\mathrm{O} / \mathrm{PH}} \mathrm{PH}_{0}+\mathrm{Y}_{\mathrm{O} / \mathrm{S}} \mathrm{CA}_{0}$

The ratio between Eqs. (8) and (9) yields the following expression:

$\frac{\mathrm{OC}}{\mathrm{OC}_{\mathrm{T}}}=\frac{\mathrm{Y}_{\mathrm{O} / \mathrm{PH}}\left(\mathrm{PH}_{0}-\mathrm{PH}\right)+\mathrm{Y}_{\mathrm{O} / \mathrm{CA}}\left(\mathrm{CA}_{0}-\mathrm{CA}\right)}{\mathrm{Y}_{\mathrm{O} / \mathrm{PH}} \mathrm{PH}_{0}+\mathrm{Y}_{\mathrm{O} / \mathrm{CA}} \mathrm{CA}_{0}}$

Figure 6a suggests that the first phase of the respirogram represents the oxidation of $\mathrm{CA}$; when the first phase ended at $t=t_{1}$, it can be assumed that CA was completely consumed (i.e., $\mathrm{CA}_{1} \cong 0$ ). Thus, according to Eq. (10), the ratio between the oxygen consumption corresponding to the first phase $\left(\mathrm{OC}_{1}\right)$ and $\mathrm{OC}_{\mathrm{T}}$ is:

$$
\frac{\mathrm{OC}_{1}}{\mathrm{OC}_{\mathrm{T}}}=\frac{\mathrm{Y}_{\mathrm{O} / \mathrm{PH}}\left(\mathrm{PH}_{0}-\mathrm{PH}_{1}\right)+\mathrm{Y}_{\mathrm{O} / \mathrm{CA}} \mathrm{CA}_{0}}{\mathrm{Y}_{\mathrm{O} / \mathrm{PH}} \mathrm{PH}_{0}+\mathrm{Y}_{\mathrm{O} / \mathrm{CA}} \mathrm{CA}_{0}}
$$

where $\mathrm{PH}_{1}$ represents the concentration of $\mathrm{PH}$ at the end of the first phase of the respirogram.
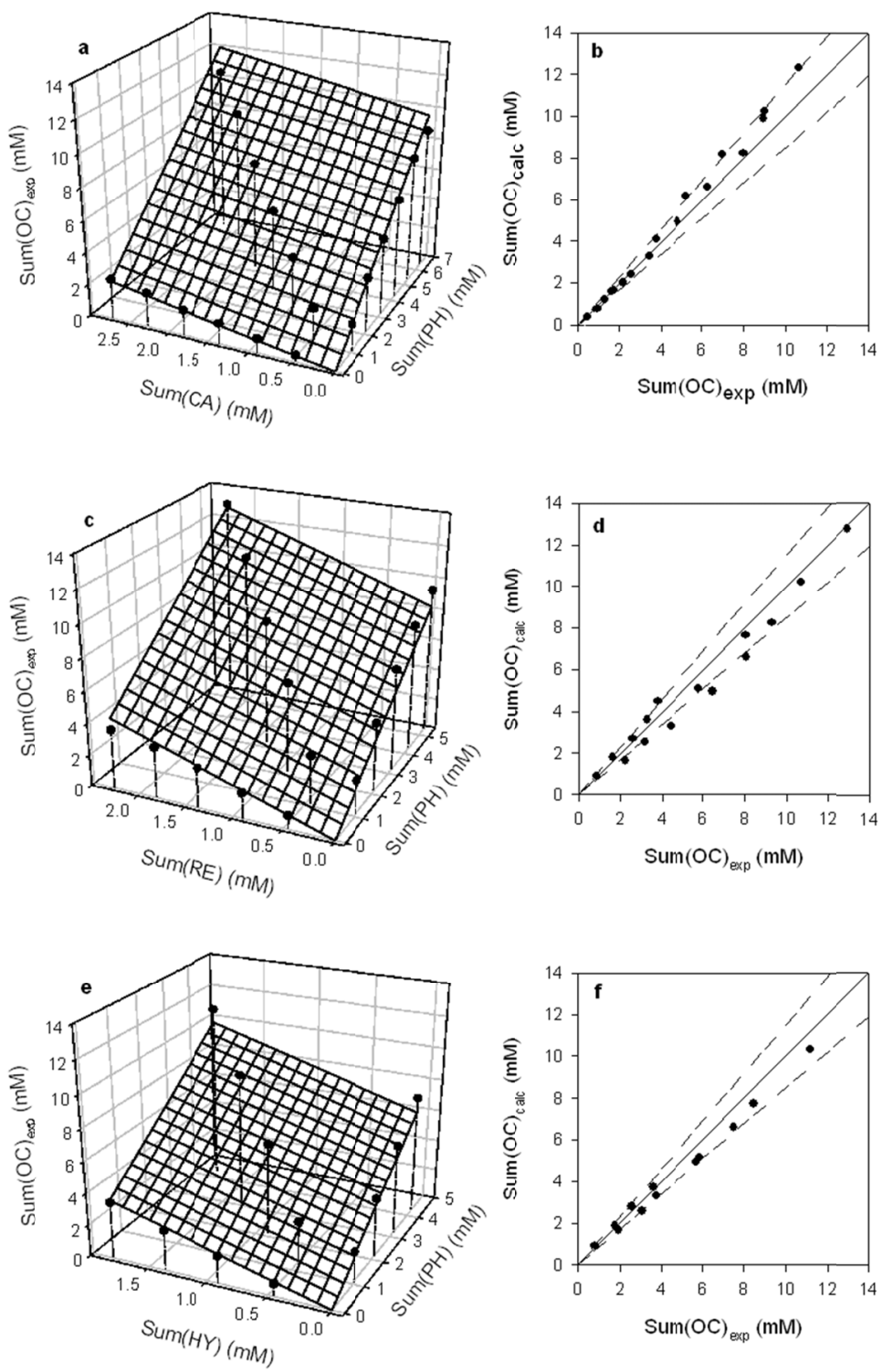

Figure 7: Cumulative oxygen consumption $(\mathrm{Sum}(\mathrm{OC}))$ as a function of the cumulative substrate concentration (Sum(S)) corresponding to the mixtures a) $\mathrm{PH}+\mathrm{CA}$, b) $\mathrm{PH}+\mathrm{RE}$ and c) $\mathrm{PH}+\mathrm{HY}$. Grey planes in a, c and e represent Eq. (7) using the oxidation coefficients depicted in Table 1. Continuous lines in $b$, $d$ and e represent the identity line; dashed lines represent $\pm 15 \%$ of the experimental value. 
Rearranging Eq. (11), the fraction of $\mathrm{PH}$ consumed during the first phase of the respirogram $\left(\mathrm{f}_{\mathrm{PH} 1}\right)$ during the oxidation of the binary mixture $\mathrm{PH}+\mathrm{CA}$ can be calculated as follows:

$$
\begin{aligned}
\mathrm{f}_{\mathrm{PH} 1} & =\frac{\mathrm{PH}_{0}-\mathrm{PH}_{1}}{\mathrm{PH}_{0}}=\frac{\mathrm{OC}_{1}}{\mathrm{OC}_{\mathrm{T}}} \\
& +\left(\frac{\mathrm{Y}_{\mathrm{O} / \mathrm{CA}} \mathrm{CA}_{0}}{\mathrm{Y}_{\mathrm{O} / \mathrm{PH}} \mathrm{PH}_{0}}\right)\left(\frac{\mathrm{OC}_{1}}{\mathrm{OC}_{\mathrm{T}}}-1\right)
\end{aligned}
$$

With regard to the mixtures $\mathrm{PH}+\mathrm{RE}$ and $\mathrm{PH}+\mathrm{HY}$, Figure $6 \mathrm{~b}, \mathrm{c}$ suggests that the first phase of these respirograms corresponded to the oxidation of $\mathrm{PH}$; thus, it can be assumed that at $t=t_{1}$ (i.e., the end of the first phase), $\mathrm{PH}$ was completely consumed $\left(\mathrm{PH}_{1}\right.$ $\cong 0$ ). Using a similar procedure, it can be demonstrated that the fraction of RE or HY consumed during the first phase of the respirogram $\left(f_{\mathrm{Z} 1}\right)$ corresponding to the oxidation of the binary mixture $\mathrm{PH}+\mathrm{RE}$ or $\mathrm{PH}+\mathrm{HY}$ is:

$$
\mathrm{f}_{\mathrm{Z} 1}=\frac{\mathrm{Z}_{0}-\mathrm{Z}_{1}}{\mathrm{Z}_{0}}=\frac{\mathrm{OC}_{1}}{\mathrm{OC}_{\mathrm{T}}}+\left(\frac{\mathrm{Y}_{\mathrm{O} / \mathrm{PH}} \mathrm{PH}_{0}}{\mathrm{Y}_{\mathrm{O} / \mathrm{Z}} \mathrm{Z}_{0}}\right)\left(\frac{\mathrm{OC}_{1}}{\mathrm{OC}_{\mathrm{T}}}-1\right)
$$

where $Z_{0}$ represents the initial concentration of $R E$ or $\mathrm{HY}$, and $Z_{1}$ is the concentration of the compound $\mathrm{Z}$ (RE or HY) at the end of the first phase of the respirogram.

Based on the respirograms shown in Figures 3 to 5 , the $\mathrm{OC}_{1}$ and $\mathrm{OC}_{\mathrm{T}}$ values corresponding to the tested binary mixtures were obtained. Then, using Eqs. (12) and (13) with the stoichiometric coefficients depicted in Table 1, the fractions of PH and RE (or HY) con sumed during the first phase of the respirogram $\left(f_{\mathrm{PH} 1}\right.$, $f_{\mathrm{Z} 1}$ ) were calculated. Table 2 shows that, in the case of the mixture $\mathrm{PH}+\mathrm{CA}$, the consumption of $\mathrm{PH}$ during the first phase of the respirogram $\left(\mathrm{f}_{\mathrm{PH} 1}\right)$ was about $5 \%$ of the initial concentration, confirming that this part mainly reflected the oxidation of CA. In the case of the mixtures $\mathrm{PH}+\mathrm{RE}$ and $\mathrm{PH}+\mathrm{HY}$, the fractions of RE and HY degraded during the first phase of the respirograms $\left(f_{\mathrm{Z} 1}\right)$ were $27 \%$ and $21 \%$, respectively.

Once these fractions $\left(f_{\mathrm{PH} 1}, f_{\mathrm{Z1}}\right)$ were obtained (Table 2), the inhibition constants $\mathrm{K}_{\mathrm{inPH} / \mathrm{CA}}, \mathrm{K}_{\mathrm{inRE} / \mathrm{PH}}$ and $\mathrm{K}_{\mathrm{inH} / \mathrm{PH}}$ were estimated as follows. For example, in the case of the binary mixture $\mathrm{PH}+\mathrm{CA}$, a set of simulations was performed using the proposed model (Eqs. (3) to (6)) with the coefficients depicted in Table 1 and assuming different $\mathrm{K}_{\mathrm{inPH} / \mathrm{CA}}$ values. Then, for each assumed $\mathrm{K}_{\mathrm{inPH} / \mathrm{CA}}$ value, the $\mathrm{PH}$ consumed during the first part of the simulated respirograms $\left(\mathrm{PH}_{1}\right)$ was evaluated. Finally, the obtained $\mathrm{PH}_{1}$ values were plotted as a function of $\mathrm{K}_{\mathrm{inPH} / \mathrm{CA}}$ (Fig. 8a). According to the experimental results depicted in Table 2, $\mathrm{PH}_{1}$ was about $5 \%$. From the comparison between the experimental and simulated $\mathrm{PH}_{1}$ values, it was concluded that the $\mathrm{K}_{\mathrm{inPH} / \mathrm{CA}}$ value was about $0.03 \mathrm{mM}$ (Fig. 8a). Based on a similar procedure, the estimated $\mathrm{K}_{\text {inRE/PH }}$ and $\mathrm{K}_{\text {inHY/PH }}$ values were 0.21 and $0.18 \mathrm{mM}$, respectively (Fig. 8b,c). Using these inhibition constants along with the kinetic coefficients shown in Table 1, Eqs. (3) to (6) were used to simulate the $\mathrm{OUR}_{\mathrm{ex}}$ profiles corresponding to the tested binary mixtures. Figure 6 shows that the model proposed in the present work adequately describes the oxygen consumption during the oxidation of binary mixtures of phenolic compounds by phenol-acclimated activated sludge.

Table 2: Oxygen consumption during the first phase of the respirogram $\left(\mathrm{OC}_{1}\right)$, total oxygen consumption

\begin{tabular}{|c|c|c|c|c|c|c|c|c|c|}
\hline & \multicolumn{3}{|c|}{$\mathbf{P H}+\mathbf{C A}$} & \multicolumn{3}{|c|}{ PH+RE } & \multicolumn{3}{|c|}{$\mathbf{P H}+\mathbf{H Y}$} \\
\hline Test number & $\begin{array}{c}\mathrm{OC}_{1} \\
(\mathrm{mM})\end{array}$ & $\begin{array}{c}\mathbf{O C}_{\mathbf{T}} \\
(\mathrm{mM})\end{array}$ & $\mathbf{f}_{\mathrm{PH} 1}(\%) *$ & $\begin{array}{c}\mathrm{OC}_{1} \\
(\mathrm{mM})\end{array}$ & $\begin{array}{c}\mathrm{OC}_{\mathrm{T}} \\
(\mathrm{mM})\end{array}$ & $\mathbf{f}_{\mathrm{RE1}}(\%) * *$ & $\begin{array}{c}\mathrm{OC}_{1} \\
(\mathrm{mM})\end{array}$ & $\begin{array}{c}\mathrm{OC}_{\mathrm{T}} \\
(\mathrm{mM})\end{array}$ & $\mathbf{f}_{\mathrm{HY} 1}(\%)^{* * *}$ \\
\hline 1 & 0.49 & 2.15 & 4.0 & 2.33 & 3.16 & 27.6 & 2.16 & 3.08 & 17.9 \\
\hline 2 & 0.39 & 1.61 & 5.8 & 2.00 & 2.63 & 34.0 & 2.00 & 2.84 & 18.7 \\
\hline 3 & 0.31 & 1.49 & 1.6 & 1.64 & 2.29 & 21.8 & 1.99 & 2.69 & 28.5 \\
\hline 4 & 0.44 & 1.75 & 6.9 & 1.94 & 2.67 & 24.7 & 1.93 & 2.73 & 19.5 \\
\hline 5 & 0.56 & 2.04 & 9.8 & 1.62 & 2.21 & 26.4 & & & \\
\hline 6 & 0.37 & 1.64 & 3.7 & & & & & & \\
\hline Mean & 0.42 & 1.78 & 5.3 & 1.91 & 2.59 & 26.9 & 2.02 & 2.84 & 21.2 \\
\hline $\begin{array}{c}\text { Confidence interval } \\
(95 \%)\end{array}$ & 0.10 & 0.27 & 3.0 & 0.36 & 0.47 & 5.6 & 0.16 & 0.28 & 7.8 \\
\hline
\end{tabular}
$\left(\mathrm{OC}_{\mathrm{T}}\right)$ and fraction of $\mathrm{PH}$ and $\mathrm{RE}$ (or HY) consumed during the first phase of the respirograms shown in Figures 3 to 5 corresponding to the binary mixtures studied.

* Eq. (12) using $\mathrm{Y}_{\mathrm{O} / \mathrm{PH}}=1.52, \mathrm{Y}_{\mathrm{O} / \mathrm{CA}}=0.87, \mathrm{PH}_{0}=1.06 \mathrm{mM}, \mathrm{CA}_{0}=0.45 \mathrm{mM}$

$* *$ Eq. (13) using $\mathrm{Y}_{\mathrm{O} / \mathrm{PH}}=1.52, \mathrm{Y}_{\mathrm{O} / \mathrm{RE}}=2.04, \mathrm{Y}_{\mathrm{O} / \mathrm{HY}}=2.05, \mathrm{PH}_{0}=1.06 \mathrm{mM}, \mathrm{RE}_{0}=0.45 \mathrm{mM}, \mathrm{HY}_{0}=0.45 \mathrm{mM}$ 

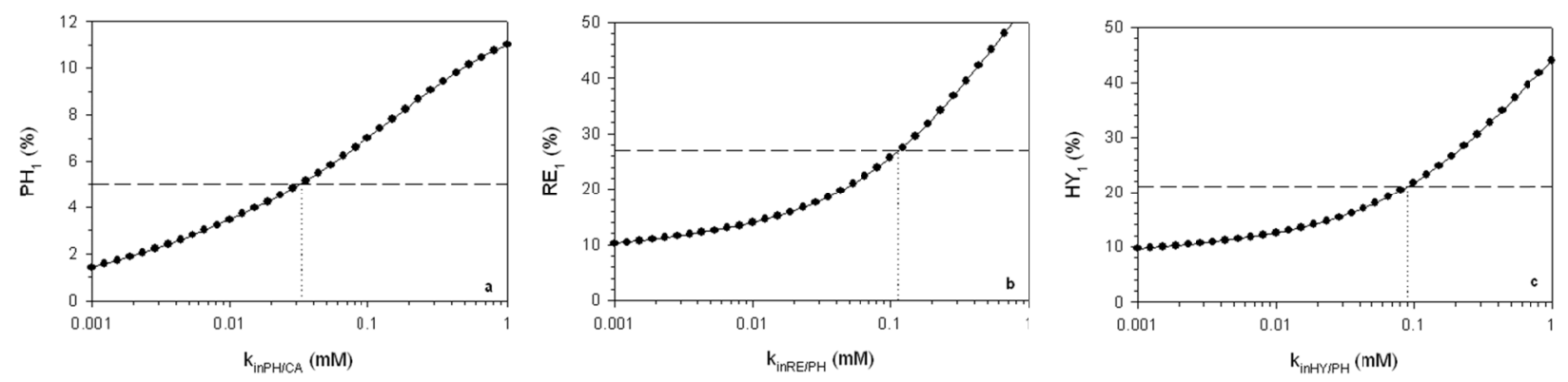

Figure 8: Effect of the inhibition constant $\left(\mathrm{K}_{\mathrm{inA} / \mathrm{B}}\right)$ on the oxidation of the substrate $\mathrm{A}(\mathrm{PH}, \mathrm{a} ; \mathrm{RE}, \mathrm{b} ; \mathrm{HY}, \mathrm{c})$ due to the presence of $\mathrm{B}(\mathrm{CA}, \mathrm{a} ; \mathrm{PH}, \mathrm{b}, \mathrm{c})$. Continuous lines represent the percentage of A consumed during the first part of the simulated respirogram $\left(\mathrm{A}_{1}\right)$ using the proposed model (Eqs. (3) to (6)) with the coefficients depicted in Table 1; dashed lines indicate experimental $A_{1}$ values (Table 2). Dotted lines indicate $K_{\text {inA/B }}$ values for which the experimental and simulated $\mathrm{A}_{1}$ values were similar.

\section{CONCLUSIONS}

This work addresses the aerobic degradation of phenol (PH), catechol (CA), resorcinol (RE) hydroquinone $(\mathrm{HY})$ and the binary mixtures $\mathrm{PH}+\mathrm{CA}$, $\mathrm{PH}+\mathrm{RE}, \mathrm{PH}+\mathrm{HY}$ by phenol-acclimated activated sludge. Based on single substrate experiments, the phenolic compounds tested can be ordered according to their substrate and oxygen consumption rates as follows: $\mathrm{CA}>\mathrm{PH}>>\mathrm{RE}>\mathrm{HY}$. Binary substrate experiments demonstrate that the presence of a second substrate only affected the kinetics, but not the stoichiometry of the oxidation of the tested compounds. CA inhibited the oxidation of $\mathrm{PH}$, for this reason, maximum $\mathrm{OUR}_{\mathrm{ex}}$ values corresponding to the mixture $\mathrm{PH}+\mathrm{CA}$ were close to those obtained during the addition of $\mathrm{CA}$ alone. While $\mathrm{PH}$ inhibited the oxidation of RE and HY, in these cases the first phase of the respirogram represented the oxidation of $\mathrm{PH}$.

A mathematical model was developed to represent the aerobic degradation of the tested phenolic compounds by phenol-acclimated activated sludge. The proposed model adequately represented the oxidation of the tested single phenolic compounds and their binary mixtures. The proposed model can be useful for predicting transient responses such as substrates and DO concentrations as a function of time in bioreactors treating phenolic wastewaters. The model could also help in designing the aeration devices of removal facilities treating phenolic wastewaters.

\section{NOMENCLATURE}

C instantaneous dissolved oxygen (DO) concentration $(\mathrm{mM})$
$\mathrm{CA}_{0} \quad$ initial catechol concentrations $(\mathrm{mM})$

$\mathrm{C}_{\mathrm{e}} \quad$ DO concentration in the absence of an oxidizable substrate $(\mathrm{mM})$

DO Dissolved oxygen (mM)

$\mathrm{Ki} \quad$ substrate inhibition coefficient $(\mathrm{mM})$

$\mathrm{K}_{\mathrm{inA} / \mathrm{B}} \quad$ inhibition constant for the consumption of A due to the presence of $B(\mathrm{mM})$

$\mathrm{K}_{\mathrm{inPH} / \mathrm{CA}}$ inhibition constant for phenol in the presence of catechol $\left(\mathrm{mM} \mathrm{h}^{-1}\right)$

$\mathrm{K}_{\mathrm{inZ/PH}}$ inhibition constant for Z (RE or HY) in the presence of phenol $\left(\mathrm{mM} \mathrm{h}^{-1}\right)$

$\mathrm{k}_{\mathrm{L}} \mathrm{a} \quad$ oxygen mass transfer coefficient $\left(\mathrm{h}^{-1}\right)$

$\mathrm{K}_{\mathrm{O} 2} \quad$ oxygen saturation coefficient (mM)

$\mathrm{K}_{\mathrm{S}} \quad$ substrate saturation coefficient $(\mathrm{mM})$

$\mathrm{OC}_{1} \quad$ oxygen consumption during the first phase of the respirogram $(\mathrm{mM})$

$\mathrm{OC}_{\mathrm{T}} \quad$ total oxygen consumed (mM)

$\mathrm{OUR}_{\mathrm{ex}}$ oxygen uptake rate associated with the substrate oxidation $\left(\mathrm{mM} \mathrm{h}^{-1}\right)$

$\mathrm{PH}_{0} \quad$ Initial phenol concentrations (mM)

$\mathrm{qO}_{2 \mathrm{~m}} \quad$ maximum specific oxygen consumption rate $\left(\mathrm{mmol} \mathrm{gTSS}^{-1} \mathrm{~h}^{-1}\right)$

qsm maximum specific substrate consumption rate $\left(\mathrm{mmol} \mathrm{gTSS}^{-1} \mathrm{~h}^{-1}\right)$

$\mathrm{R}_{\mathrm{CA}} \quad$ consumption rate corresponding to catechol $\left(\mathrm{mM} \mathrm{h}^{-1}\right)$

$\mathrm{R}_{\mathrm{PH}} \quad$ consumption rate corresponding to phenol $\left(\mathrm{mM} \mathrm{h}^{-1}\right)$

$\mathrm{R}_{\mathrm{S}} \quad$ substrate consumption rate $\left(\mathrm{mM} \mathrm{h}^{-1}\right)$

$\mathrm{R}_{\mathrm{Z}} \quad$ consumption rate corresponding to $\mathrm{Z}$, where $\mathrm{Z}$ is resorcinol or hydroquinone $\left(\mathrm{mM} \mathrm{h}^{-1}\right)$

$\mathrm{S} \quad$ substrate concentration $(\mathrm{mM})$

Sum(OC)cumulative oxygen consumption ( $\mathrm{mM})$

$\operatorname{Sum}(\mathrm{S})$ cumulative substrate concentration $(\mathrm{mM})$

$\mathrm{t}$ time (h)

$\mathrm{Y}_{\mathrm{O} / \mathrm{CA}} \quad$ oxidation coefficient for catechol $(\mathrm{mol} / \mathrm{mol})$ 
$\mathrm{Y}_{\mathrm{O} / \mathrm{PH}} \quad$ oxidation coefficient for phenol $(\mathrm{mol} / \mathrm{mol})$

$\mathrm{Y}_{\mathrm{O} / \mathrm{S}} \quad$ oxidation coefficient for $\mathrm{S}$, where $\mathrm{S}$ represents $\mathrm{CA}, \mathrm{RE}$ or $\mathrm{HY}(\mathrm{mol} / \mathrm{mol})$

$\mathrm{Z}_{0} \quad$ initial concentration of RE or HY $(\mathrm{mM})$

\section{ACKNOWLEDGEMENTS}

This work was supported by Consejo Nacional de Investigaciones Científicas y Técnicas (CONICET), by Universidad Nacional de la Plata (UNLP), and by Agencia Nacional de Promoción Científica y Tecnológica (ANPCyT), Argentina.

\section{REFERENCES}

Ahuatzi-Chacón, D., Ordorica-Morales, G., RuizOrdaz, N., Cristiani-Urbina, E., Juárez-Ramírez, C., Galíndez-Mayer, J., Kinetic study of phenol hydroxylase and catechol 1,2-dioxygenase biosynthesis by Candida tropicalis cells grown on different phenolic substrates. World Journal of Microbiology and Biotechnology, 20, 695-702 (2004).

Arutchelvan, V., Kanakasabai, V., Elangovan, R., Nagarajan, S., Muralikrishnan, V., Kinetics of high strength phenol degradation using Bacillus brevis. Journal of Hazardous Materials, 129, 216222 (2006).

Bajaj, M., Gallert, C., Winter, J., Biodegradation of high phenol containing synthetic wastewater by an aerobic fixed bed reactor. Bioresource Technology, 99, 8376-8381(2008).

Busca, G., Berardinelli, S., Resini, C., Arrighi, L., Technologies for the removal of phenol from fluid streams: A short review of recent developments. Journal of Hazardous Materials, 160, 265288 (2008).

Contreras, E. M., Albertario, M. E., Bertola, N. C., Zaritzky, N. E., Modelling phenol biodegradation by activated sludges evaluated through respirometric techniques. Journal of Hazardous Materials, 158, 366-374 (2008).

Christen, P., Vega, A., Casalot, L., Simon, G., Auria, R., Kinetics of aerobic phenol biodegradation by the acidophilic and hyperthermophilic archaeon Slufolobus solfataricus 98/2. Biochem. Eng. J., 62, 56-62 (2012).

Detmer, K., Massey, V., Effect of substrate and $\mathrm{pH}$ on the oxidative half-reaction of phenol hydroxylase. The Journal of Biological Chemistry, 260, 5998-6005 (1985).

Divari, S., Valetti, F., Caposio, P., Pessione, E.,
Cavaletto, M., Griva, E., Gribaudo, G., Gilardi, G., Giunta, C., The oxygenase component of phenol hydroxylase from Acinetobacter radioresistens S13. European Journal of Biochemistry, 270, 2244-2253 (2003).

Edwards, J. D., Industrial Wastewater Treatment: A Guidebook, Florida (1995).

Enroth, C., Neujahr, H., Schneider, G., Lindqvist, Y., The crystal structure of phenol hydroxylase in complex with FAD and phenol provides evidence for a concerted conformational change in the enzyme and its cofactor during catalysis. Structure, 6, 605-617 (1998).

Guisasola, A., Baeza, J. A., Carrera, J., Sin, G., Vanrolleghem, P. A., Lafuente, J., The influence of experimental data quality and quantity on parameter estimation accuracy: Andrews inhibition model as a case study. Education for Chemical Engineers 1, 139-145 (2006).

Gujer, W., Henze, M., Mino, T., Loosdrecht, M. V., Activated sludge model No. 3. Water Science and Technology, 39, 183-193 (1999).

Henze, M., Grady, C. P. L. J., Gujer, W., Marais, G. V., Matsuo, T., Activated Sudge Model No. 1. IAWPRC Scientific and Technical Report No. 1, London (1987).

Henze, M., Gujer, W., Mino, T., Matsuo, T., Wentzel, M. C., Marais, G. V. R., van Loosdrecht, M. C. M., Activated sludge model No.2D, ASM2D. Water Science and Technology 39, 165-182 (1999).

Henze, M., Harremoes, P., Jansen, J. L., Arvin, E., Wastewater Treatment. Biological and Chemical Processes, London (2002).

Houari, M., Hamdi, B., Bouras, O., Bollinger, J.-C., Baudu, M., Static sorption of phenol and 4nitrophenol onto composite geomaterials based on montmorillonite, activated carbon and cement. Chemical Engineering Journal, 255, 506-512 (2014).

Inchaurrondo, N., Contreras, E., Haure, P., Catalyst reutilization in phenol homogeneous cupro-Fenton oxidation. Chemical Engineering Journal, 251, 146157 (2014).

INDSPEC, High Production Volume (HPV) Challenge Program. Data Analysis and Test Plan for Resorcinol. CAS Number 108-46-3, Chemical Corporation, Pittsburgh (2004).

Karigar, C., Mahesh, A., Nagenahalli, M., Yun, D. J., Phenol degradation by immobilized cells of Arthrobacter citreus. Biodegradation, 17, 47-55 (2006).

Kumar, A., Kumar, S., Biodegradation kinetics of phenol and catechol using Pseudomonas putida MTCC 1194. Biochemical Engineering Journal, 22, 151-159 (2005). 
Lepik, R., Tenno, T., Biodegradability of phenol, resorcinol and 5- methyl resorcinol as single and mixed substrates by activated sludge. Oil Shale, 28, 425-443 (2011).

Lobo, C. C., Bertola, N. C., Contreras, E. M., Stoichiometry and kinetic of the aerobic oxidation of phenolic compounds by activated sludge. Bioresource Technology, 136, 58-65 (2013).

Lobo, C. C., Bertola, N. C., Contreras, E. M., Error propagation in open respirometric assays. Brazilian Journal of Chemical Engineering, 31, 303-312 (2014).

Mendes, P., GEPASI: A software package for modelling the dynamics, steady states and control of biochemical and other systems. Computer applications in the biosciences: CABIOS 9, 563-571 (1993).

Nuhoglu, A., Yalcin, B., Modelling of phenol removal in a batch reactor. Process Biochemistry, 40, 1233-1239 (2005).

Orupõld, K., Maširin, A., Tenno, T., Estimation of biodegradation parameters of phenolic compounds on activated sludge by respirometry. Chemosphere, 44, 1273-1280 (2001).

Pramparo, L., Suárez-Ojeda, M. E., Pérez, J., Carrera,
J., Kinetics of aerobic biodegradation of dihydroxybenzenes by a p-nitrophenol-degrading activated sludge. Bioresource Technology, 110, 57-62 (2012).

Sejlitz, T., Neujahr, H. Y., Phenol hydroxylase from yeast. European Journal of Biochemistry, 170, 343-349 (1987).

Tziotzios, G., Teliou, M., Kaltsouni, V., Lyberatos, G., Vayenas, D. V., Biological phenol removal using suspended growth and packed bed reactors. Biochemical Engineering Journal, 26, 65-71 (2005).

US-EPA, Toxicological Review. Phenol. CAS No. 108-95-2. U.S. EPA, Washington DC (2000).

Vanrollehem, P. A., Gillot, S., Robustness and economic measures as control benchmark performance criteria. Water Science and Technology, 45, 117-126 (2002).

Wang, W., Liu, Y., Li, T., Zhou, M., Heterogeneous Fenton catalytic degradation of phenol based on controlled release of magnetic nanoparticles. Chemical Engineering Journal, 242, 1-9 (2014).

Yoong, E. T., Lant, P. A., Greenfield, P. F., In situ respirometry in an SBR treating wastewater with high phenol concentrations. Water Research, 34, 239-245 (2000). 